\title{
Physalis angulata induces in vitro differentiation of murine bone marrow cells into macrophages
}

\author{
Bruno José Martins da Silva ${ }^{1,2}$, Ana Paula D Rodrigues ${ }^{2,3}$, Luis Henrique S Farias ${ }^{1,2}$, Amanda Anastácia P Hage ${ }^{1,2}$, \\ Jose Luiz M Do Nascimento ${ }^{4}$ and Edilene O Silva ${ }^{1,2^{*}}$
}

\begin{abstract}
Background: The bone marrow is a hematopoietic tissue that, in the presence of cytokines and growth factors, generates all of the circulating blood cells. These cells are important for protecting the organism against pathogens and for establishing an effective immune response. Previous studies have shown immunomodulatory effects of different products isolated from plant extracts. This study aimed to evaluate the immunomodulatory properties of aqueous Physalis angulata (AEPa) extract on the differentiation of bone marrow cells.
\end{abstract}

Results: Increased cellular area, higher spreading ability and several cytoplasmatic projections were observed in the treated cells, using optical microscopy, suggesting cell differentiation. Furthermore, AEPa did not promote the proliferation of lymphocytes and polymorphonuclear leukocytes, however promotes increased the number of macrophages in the culture. The ultrastructural analysis by Transmission Electron Microscopy of treated cells showed spreading ability, high number of cytoplasmatic projections and increase of autophagic vacuoles. Moreover, a high level of LC3b expression by treated cells was detected by flow cytometry, suggesting an autophagic process. Cell surface expression of F4/80 and CD1 1b also indicated that AEPa may stimulate differentiation of bone marrow cells mainly into macrophages. In addition, AEPa did not differentiate cells into dendritic cells, as assessed by CD11c analysis. Furthermore, no cytotoxic effects were observed in the cells treated with AEPa.

Conclusion: Results demonstrate that AEPa promotes the differentiation of bone marrow cells, particularly into macrophages and may hold promise as an immunomodulating agent.

Keywords: Cell differentiation, Bone marrow cells, Physalis angulata

\section{Background}

The hematopoietic tissue, bone marrow, is responsible for generating all circulating blood cells [1]. Hematopoietic stem cells undergo the process of maturation and differentiation in the presence of cytokines and growth factors present in the marrow microenvironment, giving rise to myeloid and lymphoid progenitor cells $[2,3]$. These myeloid progenitors, when stimulated, differentiate and give rise to blood cells, macrophages and dendritic cells (DCs), while the lymphoid lineage differentiates into $\mathrm{T}$ and $\mathrm{B}$ lymphocytes, natural killers (NK) cells and DCs $[4,5]$.

\footnotetext{
* Correspondence: edilene@ufpa.br

'Instituto de Ciências Biológicas, Laboratório de Parasitologia e Laboratório de Biologia Estrutural, Universidade Federal do Pará, Avenida Augusto Corrêa, 01, Bairro Guamá, 660975-110 Belém, Pará, Brazil

${ }^{2}$ Instituto Nacional de Ciência e Tecnologia em Biologia Estrutural e

Bioimagem, Rio de Janeiro, Brazil

Full list of author information is available at the end of the article
}

The monocytes belong to the mononuclear phagocytic system and constitute about 3 to $8 \%$ of circulating leukocytes in the blood [6,7]. After three days in the circulating blood, monocytes begin the migration process to tissues where they differentiate into macrophages and DCs [6,7]. During the differentiation of monocytes into macrophages, several cellular changes are observed, such as increased cell size, increased number of organelles and the induction of the autophagic process [8,9]. Autophagy is essential for monocyte-macrophage differentiation; reports demonstrate that some monocytes cannot survive if the autophagy process is blocked and, if they are to survive, the differentiation process becomes defective inhibiting differentiation of cells into macrophages [9].

Macrophages express specific molecules on their surface, including the $\mathrm{F} 4 / 80$ and $\mathrm{CD} 11 \mathrm{~b} / \mathrm{MAC}-1$ proteins, which are markers of the differentiation process and allow macrophages to differentiate into other cell types 
$[10,11]$. These molecules are also involved in the process of cell adhesion and in the migration to sites of intracellular pathogen invasion [10]. Macrophages are important for maintaining an efficient innate immune response, having the ability to migrate to the site of invasion, recognizing the aggressor, phagocytosing and eliminating the pathogen $[3,12]$.

In recent years, there has been a growing interest in the use of natural products to induce proliferation and differentiation of bone marrow cells [13-16]. In this context, Physalis angulata $(\mathrm{Pa})$, which is a herbaceous plant, has been reported to possess several activities, among them, diuretic, antipyretic, analgesic [17], antinociceptive, anti-inflammatory and immunomodulatory [18,19] properties. Phytochemical studies of $P$. angulata demonstrate that extracts from this plant contains glucocorticoids, flavonoids, physalins (D, I, G, K, B, F, E), physagulins (E, F and $G$ ), and withanolides $[20,21]$. It is possible that the immunomodulatory effects of this plant may occur due to hematopoietic-supportive activities, through the activation of resident macrophages, which undergo several morphological changes, such as an increase in spreading and adhesion abilities, phagocytosis activity, ROS generation, antigen presentation and cytokine production. Therefore, the aim of this study was to evaluate the modulatory activity of AEPa on the cell differentiation process of monocyte-derived bone marrow cells in macrophages.

\section{Methods}

Preparation of the aqueous extract from roots of Physalis angulata (AEPa)

Roots of the Physalis angulata (Solanaceae) plant were collected in Pará state, Brazil. Roots were cut to produce the aqueous extract. AEPa was prepared as described by Bastos et al. [18]. The voucher specimen (no. 563) was deposited in the herbarium of the Emilio Goeldi Museum (Belém, Pará, Brazil). One $\mathrm{mg} / \mathrm{mL}$ of aqueous extract from the root of Physalis angulata (AEPa) was dissolved in Dulbecco's Modified Eagle's Medium (DMEM) or RPMI and used as the standard solution for assays.

\section{Bone marrow cells isolation}

Bone marrow cells (BMCs) were isolated from the femurs of male mice BALB/c (Mus musculus) aged 6-12 weeks. The animals were sacrificed in a $\mathrm{CO}_{2}$ chamber (Insight $t^{\circ}$ ) and the femurs were dissected under laminar flow and washed with sterile phosphate buffered saline (PBS). The epiphyses were then removed [22], and cells were homogenized and diluted in DMEM containing $10 \%$ FBS, maintained in 12,24 or 96 -well plates at $37^{\circ} \mathrm{C}$ in a $5 \% \mathrm{CO}_{2}$ atmosphere. The experiments and study were carried out in accordance with current Brazilian animal protection laws (Lei Arouca number 11.794/08) in compliance with the National Council for the Control of Animal Experimentation (CONCEA, Brazil). The protocol was approved by the Committee on the Ethics of Animal Experiments of the Federal University of Pará (CEPAE/ICB/UFPA - grant number 086-12).

\section{Treatment of bone marrow cells}

BMCs were cultured in the presence of $100 \mu \mathrm{g} / \mathrm{mL}$ of $\operatorname{AEPa}(1 \mathrm{mg} / \mathrm{mL}$ stock solution) for $24,48,72$ and 96 hours. In some assays, BMCs were treated with 100 nM macrophage colony-stimulating factor (M-CSF), as positive control for differentiation. M-CSF and AEPa were added to the cultures every 24 hours until the end of each test, without replacing the culture medium.

\section{Cell viability tests}

To assess the viability of the BMCs treated with AEPa, three tests were performed as described below.

\section{Method Thiazolyl Blue (MTT)}

MTT is a soluble salt, which is converted by mitochondrial dehydrogenases into formazan blue crystal. This assay is based on the mitochondrial-dependent reduction of 3-(4,5-dimethylthiazol-2-yl)-2,5-diphenyl tetrazolium bromide (MTT) to formazan. The procedure was performed according to Fotakis and Timbrell [23], with some modifications.

BMCs were cultured and treated with 25, 50 or $100 \mu \mathrm{g} / \mathrm{mL}$ AEPa for 24, 48, 72 and 96 hours. Subsequently, cells were incubated with $0.5 \mathrm{mg} / \mathrm{mL}$ MTT diluted in PBS and incubated at $37^{\circ} \mathrm{C}$ in a humidified atmosphere containing $5 \% \mathrm{CO}_{2}$ for 3 hours. Two-hundred $\mu \mathrm{L}$ of DMSO were added to each well to solubilize formazan crystals and the plate was incubated under agitation for 10 minutes. The resulting solution was read in a microplate reader (BIO-RAD Model 450 Microplate Reader) and absorbance was recorded at an optical density (OD) of $570 \mathrm{~nm}$. As a negative control, cells were killed with a $15 \%$ solution of formaldehyde in PBS.

\section{Detection of the mitochondrial membrane potential (JC-1)}

JC-1 is a fluorescent dye that measures the mitochondrial membrane potential $(\Delta \Psi)$ of cells. The loss of this potential serves as an indicator of apoptosis, where this dye remains in its monomeric form and emits a green fluorescence. Living cells form the "J-aggregates" which emit a red fluorescence.

BMCs were treated with $100 \mu \mathrm{g} / \mathrm{mL}$ AEPA for 96 hours. Subsequently, cells were incubated with JC-1 $(1 \mu \mathrm{M})$ for $30 \mathrm{~min}$ at $37^{\circ} \mathrm{C}$. After incubation, the cells were washed and resuspended in PBS. Fluorescence data were obtained using a flow cytometer (BD FACSCantoII $\mathrm{TM}$ ) at an excitation wavelength of $488 \mathrm{~nm}$, where JC-1 monomers emit fluorescence at $529 \mathrm{~nm}$ and J-aggregates emit at $590 \mathrm{~nm}$. A total of 10.000 events were acquired 
for each sample and the data were obtained by flow cytometer BD FACSCantoII. The data were analyzed using WinMDI version 2.9 (Joseph Trotter) software. The gate was determined using unstained BMCs controls (Additional file 1). The data were analyzed using WinMDI version 2.9 (Joseph Trotter) software.

\section{Detection of apoptosis and necrosis of BMCs treated with AEPa}

For detection of apoptosis and necrosis of BMCs treated with AEPA, Annexin V-FITC (Invitrogen) and PI (Sigma) were used, respectively. BMCs were treated with $100 \mu \mathrm{g} /$ $\mathrm{mL} \mathrm{AEPa}$ and cultured for 96 hours. After treatment, these cells were incubated for 30 minutes with $10 \mu \mathrm{g} / \mathrm{mL}$ Annexin V-FITC and then incubated with $25 \mu \mathrm{g} / \mathrm{mL}$ PI for 30 minutes. Finally, the cells were washed with PBS and data obtained by flow cytometry. A total of 10.000 events were acquired for each sample in the region that corresponded to the BMCs and the gates were determined using unstained controls (Additional file 1).

\section{Light microscopy (LM)}

BMCs were cultured and treated for 24, 48, 72 and 96 hours before dividing into three groups, control (non treated cells), treated with AEPa and M-CSF. Cells were fixed in a solution containing 3\% paraformaldehyde in PHEM buffer (5 mM magnesium chloride, $70 \mathrm{mM}$ potassium chloride, $10 \mathrm{mM}$ EGTA, $20 \mathrm{mM}$ HEPES, $60 \mathrm{mM}$ PIPES), $0.1 \mathrm{M} \mathrm{pH} \mathrm{7.2,} \mathrm{stained} \mathrm{with} \mathrm{Giemsa} \mathrm{and} \mathrm{covered}$ with Entellan ${ }^{\bullet}$ (Merck). Two hundred cells were counted per coverslip. Differentiated cell types such as lymphocytes, mononuclear phagocytes (monocytes and macrophages) and polymorphonuclear (PMN) were identified according to their morphological characteristics. Cells were counted and analyzed using an Olympus BX41 microscope.

\section{Morphometric analysis}

The cytoplasmic area of the control group and treated BMCs $(100 \mu \mathrm{g} / \mathrm{mL}$ of AEPa for 96 hours) was analyzed using the program Image $\mathrm{J}(\mathrm{NHI})$ software and images were obtained by light microscopy. This analysis was performed as described by Sokol et al. [24].

\section{Transmission Electron Microscopy (TEM)}

Control and treated BMCs were fixed with $2.5 \%$ glutaraldehyde and $4 \%$ paraformaldehyde in $0.1 \mathrm{M}$ sodium cacodylate buffer, pH7.2. The cells were washed in the same buffer and incubated in 1\% osmium tetroxide and $0.8 \%$ potassium ferricyanide for 1 hour. The cells were dehydrated in graded acetone $(50 \%, 70 \%, 90 \%$ and $2 \times 100 \%)$ and embedded in Epon resin (2:1, 1:1 and 1:2 - 100\% acetone: Epon). Thin sections were contrasted with 5\% uranyl acetate and lead citrate and finally observed with a LEO 906 E Transmission Electron Microscope.

\section{Detection of LC3b protein by flow cytometry}

Treated and untreated BMCs were fixed with 3\% paraformaldehyde and 0.1 M PHEM buffer, $\mathrm{pH} 7.2$, for 30 minutes. Subsequently, cells were permeabilized with $0.1 \%$ Triton $\mathrm{X}-100$, washed in PBS and incubated with $50 \mathrm{mM} \mathrm{NH}_{4} \mathrm{Cl}$ in PBS for 40 minutes.

The cells were incubated with polyclonal anti-LC3b antibody (Invitrogen Molecular Probes ${ }^{\odot}$ ) diluted 1:1000 in PBS with 1\% BSA for 1 hour, then washed in PBS and incubated with a fluorescent secondary antibody (Alexa Fluor 488-labelled goat anti-rabbit IgG; Molecular Probes Invitrogen ${ }^{\odot}$ ) diluted 1:100 in PBS for 30 minutes. Data were obtained by flow cytometry (BD FACSCantoII) at an excitation wavelength of $488 \mathrm{~nm}$. The results were analyzed by WinMDI version 2.9 (Joseph Trotter). For induction of autophagy, BMCs were cultured for 96 hours, washed with PBS and incubated for 3 hours with phosphate buffer, $\mathrm{pH} 7.2$, at $37^{\circ} \mathrm{C}$ in $5 \% \mathrm{CO}_{2}$ and used as a positive control for the autophagic process.

\section{Detection of cell surface markers by flow cytometry}

Treated and untreated BMCs were fixed with 3\% paraformaldehyde and 0.1 M PHEM buffer, $\mathrm{pH}$ 7.2, for 30 minutes. Cells were washed in PBS, $\mathrm{pH}$ 8.0, and incubated with $50 \mathrm{mM} \mathrm{NH}_{4} \mathrm{Cl}$ in PBS for 40 minutes. Next, the cells were incubated for 1 hour with anti-CD11c monoclonal antibody (DCs marker), anti-CD11b (Mac-1) and anti- F4/80 monoclonal antibody (mononuclear cells and macrophage markers, respectively), diluted 1:50 in PBS. Subsequently, cells were incubated with fluorescent secondary antibody conjugated with PE-goat anti-rat IgG, diluted 1:50 in PBS for 40 minutes. A positive control was treated with M-CSF $(100 \mathrm{mM})$ and also maintained in parallel. All experiments were performed at least three times with treated and untreated cells. Data were obtained by flow cytometry (BD FACSCantoII) at an excitation wavelength of $546 \mathrm{~nm}$ and analyzed by WinMDI version 2.9 (Joseph Trotter) software.

\section{Statistical Analysis}

All experiments were performed in triplicate and the results were analyzed by GraphPad Prism 5 (GraphPad Software, La Jolla, CA, USA). The means and S.D. of at least three experiments were determined. Analysis of variance (ANOVA) and Student's t-test were used to compare data. The Tukey test was applied when necessary. All p-values $<0.05$ were considered as statistically significant.

\section{Results}

\section{Effect of AEPa on BMCs cell viability}

BMCs were treated with 25, 50 and $100 \mu \mathrm{g} / \mathrm{mL}$ AEPa for 24-96 $\mathrm{h}$ and cell viability analyzed by the MTT assay (Figure 1a). Alternatively, BMCs were treated with $100 \mu \mathrm{g} / \mathrm{mL}$ for 96 hours and loaded with JC-1 (Figure $1 \mathrm{~b} 1$ and 1b2) or stained with PI and Annexin-V (Figure 1 


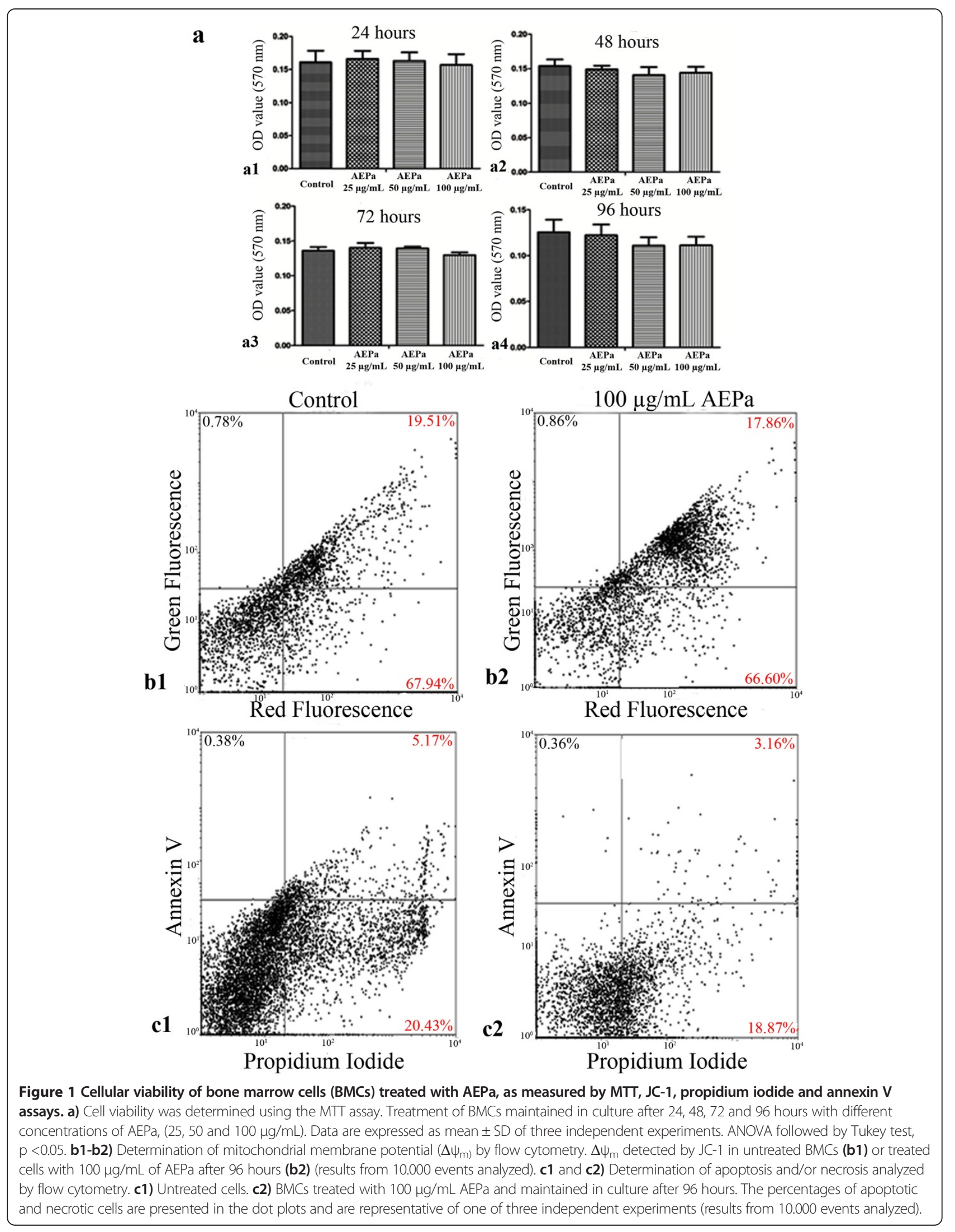


c1 and 1 c2). No cytotoxic effect of AEPa was observed in cells treated for 24, 48, 72 and 96 hours, when compared to the control group, as shown by the MTT assay. Labeling with JC-1 and PI and annexin-V demonstrated that treated cells remain viable following 96 hours of culture.

\section{Quantitative analysis of adherent cells}

To evaluate the effect of AEPa on the BMCs, a quantitative analysis was performed and identified the following cell types, including lymphocytes, PMN and mononuclear phagocytes.

\section{Lymphocytes}

Lymphocytes were characterized as cells with a small cytoplasmic area and large nucleus. From 96 hour of treatment, a reduction of $40 \% \pm 8$ in the number of lymphocytes was observed when compared with untreated cells (Figure 2a).

\section{PMN cells}

PMN cells have two or more nuclei arranged in the cytoplasm. No significant difference was observed between the control group and the group treated with AEPa for 96 hours (Figure 2b).

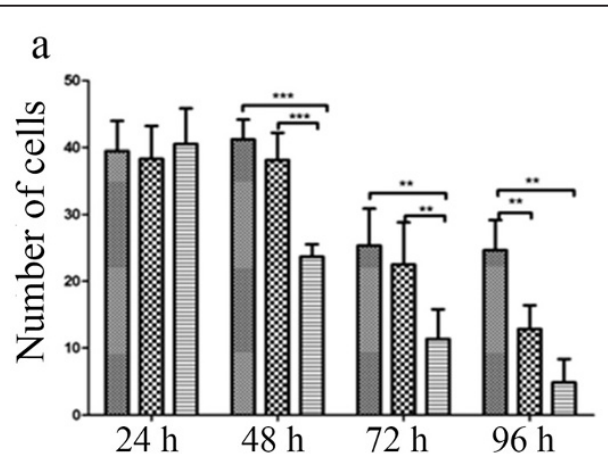

\section{Control \\ $\square 00 \mu \mathrm{g} / \mathrm{mL}$ AEPa
$\square 100 \mathrm{nM}$ M-CSF}

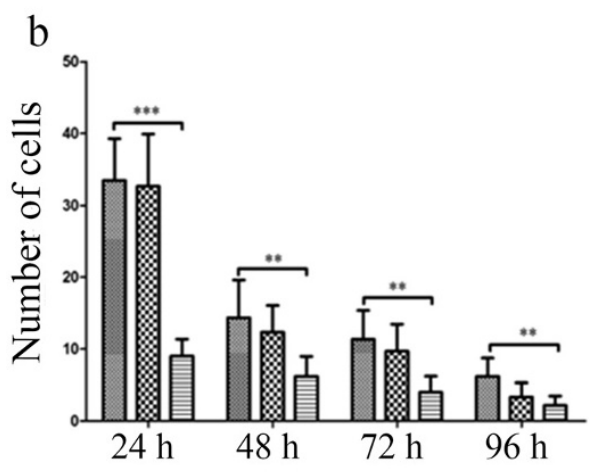
Control
$\$ 100 \mu \mathrm{g} / \mathrm{mL} \mathrm{AEPa}$

曰100 nM M-CSF
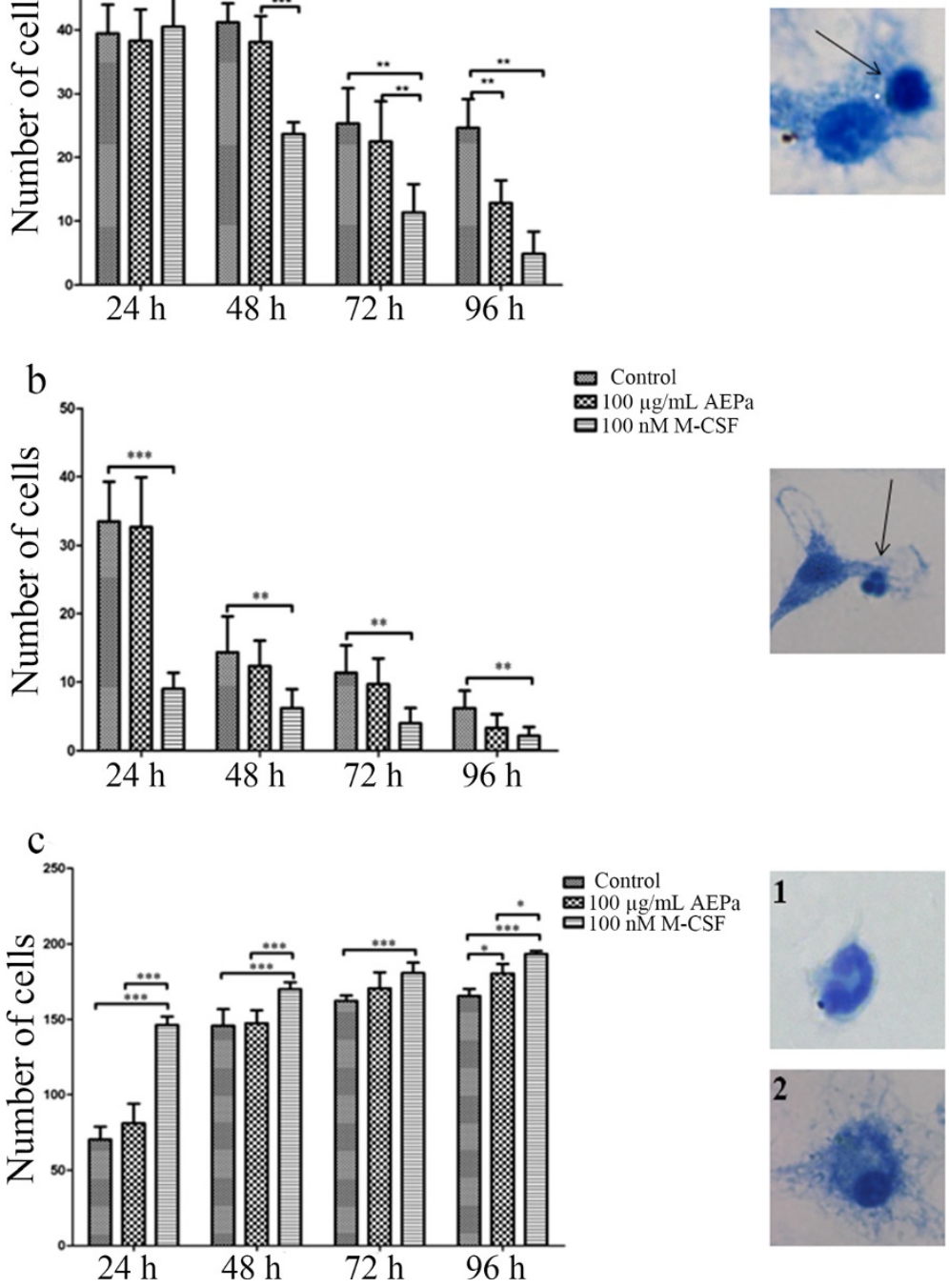

Figure 2 Differential cell count in BMCs cultures after 24, 48, $\mathbf{7 2}$ and 96 hours. Cells were treated with $100 \mu \mathrm{g} / \mathrm{mL}$ of AEPa, $100 \mathrm{nM}$ of M-CSF and compared to the control group. a) Lymphocytes. Inset, lymphocytes (arrow), cells with a small cytoplasmic area and large nucleus. b) Polymorphonuclear. Inset, showing polymorphonuclear (arrow), cells with two or more nuclei arranged in the cytoplasm. c) Mononuclear phagocytes. Inset 1, showing monocyte, cell with a small cytoplasmic area and nucleus in a horseshoe shape and, inset 2 showing macrophage, cell with a large nucleus and evident cytoplasm. The values are expressed as means \pm SD and compared with the control group. ANOVA, followed by Tukey test, $\mathrm{p}<0.05$. 


\section{Mononuclear cells}

Mononuclear cells constitute monocytes (cells with a small cytoplasmic area and nucleus in a horse-shoe shape) and macrophages (large nucleus and evident cytoplasm). A significant increase in the number of cells with macrophage characteristics was observed in the cultures treated with AEPa $(8 \% \pm 3)$ for 96 hours, when compared to the control group (Figure 2c).

\section{AEPa induces morphological alterations and increases cellular area in BMCs}

Control and BMCs treated with AEPa were analyzed by LM and TEM. Morphological alterations were observed in $100 \mu \mathrm{g} / \mathrm{mL} \mathrm{AEPa-treated} \mathrm{cells} \mathrm{that} \mathrm{were} \mathrm{characteristic}$ of activated cells. An increase in cytoplasmic area, spreading ability and a high number of cytoplasmatic projections were also observed (Figure 3b). Morphometric analysis showed significant increase in the area occupied by cytoplasm in cells treated with $\mathrm{AEPa}$, when compared to the control group (Figure $3 \mathrm{~d}$ ).

To investigate possible ultrastructural changes in cells treated with AEPa, TEM was performed. BMCs treated with AEPa presented nuclei with abundant euchromatin, an apparently increased number of endoplasmic reticuli (ER), numerous mitochondria, which are characteristic of intense cell metabolism, and numerous cellular projections (Figure 4c and d). The presence of cytoplasmic vacuoles and structures suggestive of autophagic vacuoles were observed in the cytoplasm of AEPa-treated cells (Figure $5 \mathrm{a}$ and $\mathrm{b}$ ).

\section{Induction of autophagy in BMCs}

To test whether AEPa induces autophagy in BMCs, cells were treated for 96 hours and the expression of LC3b evaluated by flow cytometry. LC3b is a specific marker for autophagy in mammalian cells; treated BMCs presented higher fluorescence intensity when compared to the untreated control group. The staining of cells treated with AEPa was similar to that of the control group after starvation and to that of the group of cells treated with M-CSF (Figures 5c-g).

\section{Detection of cell surface markers by flow cytometry}

To determine whether AEPa promotes the differentiation of BMCs into macrophages, the expressions of the surface proteins F4/80, CD11b and CD11c were assessed on BMCs by flow cytometry. An increased of expression of CD11b (Figure 6c) and F4/80 (Figure 6h and 6j) and were observed on AEPa-treated cells. The same expression levels were observed in the positive-control groups, consisting of peritoneal macrophages (Figure 6a, for CD11b and 6f for F4/80) and BMCs stimulated with M-CSF (Figure 6d for CD11b and 6i for F4/80), in comparison with untreated cells. Analysis of the fluorescence intensity showed that there was a decreased staining of CD11b protein in AEPa-treated cells as also

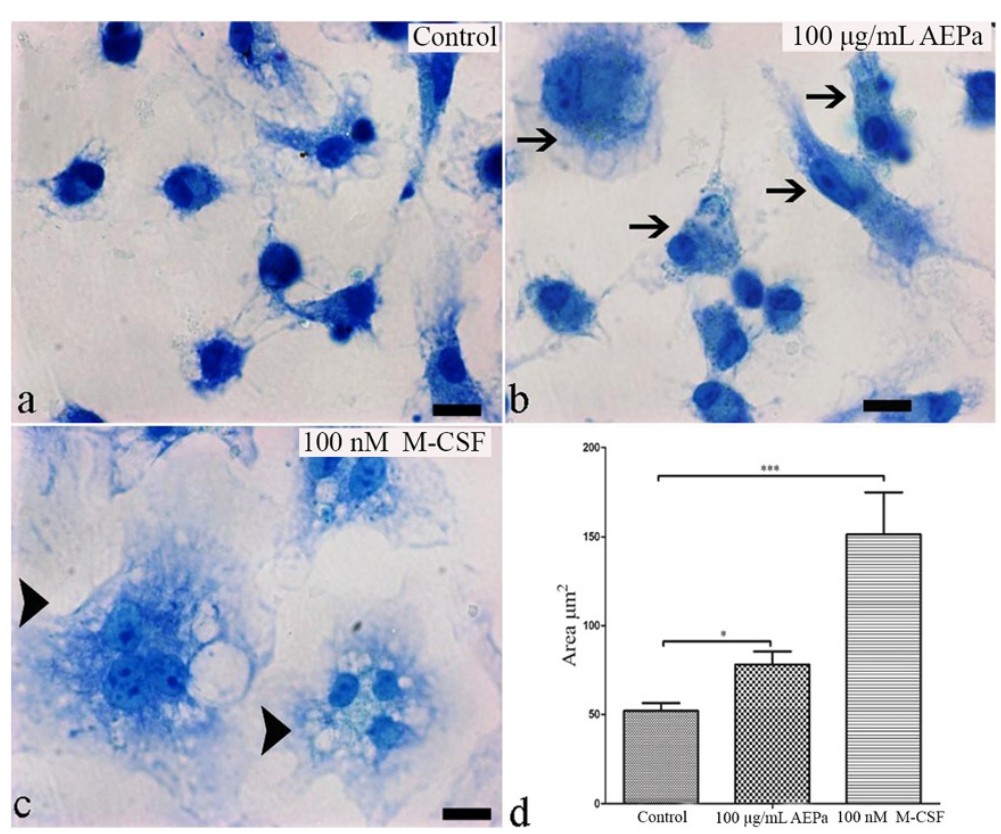

Figure 3 Cytological evaluation of BMCs using Giemsa stain. Treated cells were incubated for 96 hours. a) Untreated cells. b) Cells treated with $100 \mu \mathrm{g} / \mathrm{mL} \mathrm{AEPa}$, note the increased cell spreading, cytoplasmic volume and cells with characteristics of activated macrophages (arrow). c) Cells treated with $100 \mathrm{nM}$ of M-CSF. Cells after treatment with M-CSF presented a significant spreading ability, increased cellular area and most of the cells are undergoing cell fusion processes (head arrows). Scale bar $10 \mu \mathrm{m}$. d) Morphometric analysis showed increased cell area for cells treated with AEPa or M-CSF, compared with control cells. Data are presented as means $\pm S D, p<0.05$ 


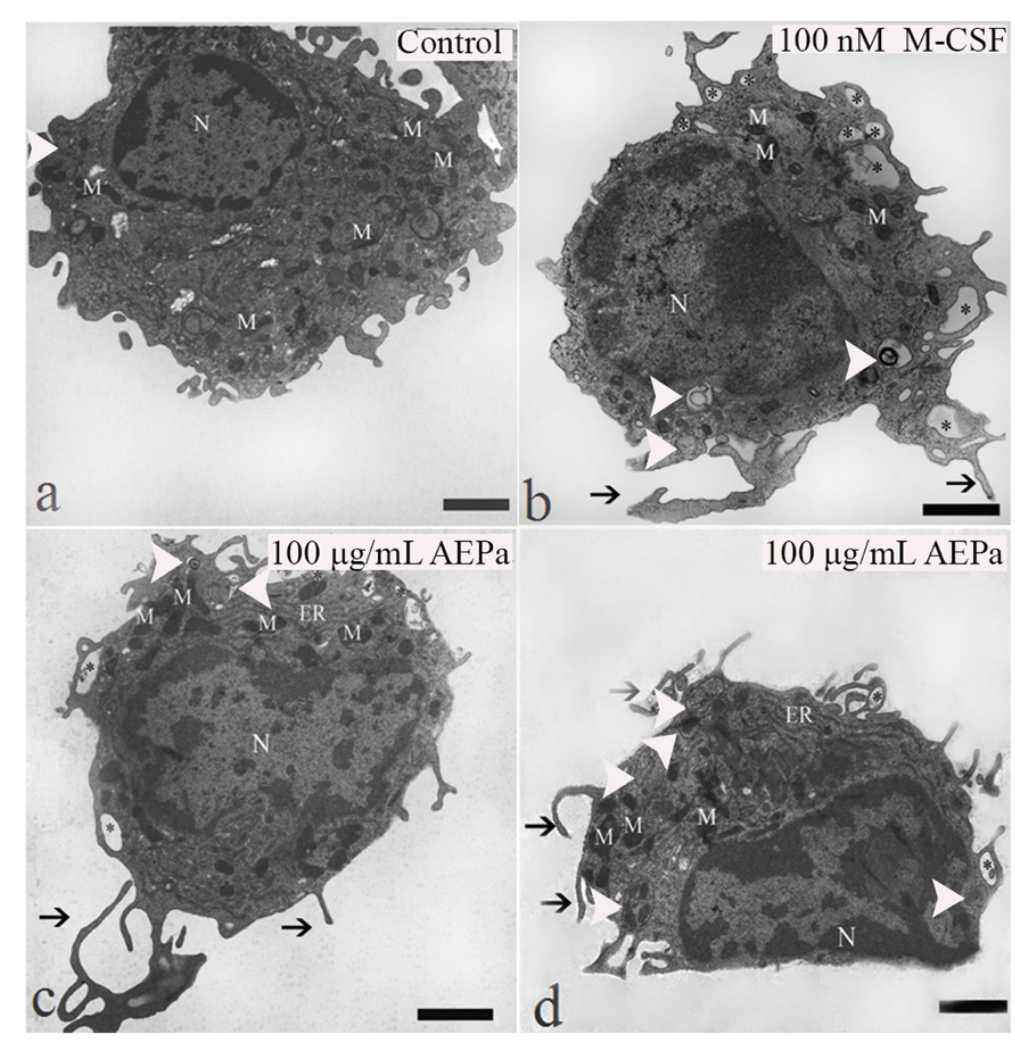

Figure 4 Ultrastructural analysis of BMCs. Treated cells were incubated for 96 hours. a) Untreated control. b) Cells treated with 100 nM M-CSF. c, d) Cells treated with $100 \mu \mathrm{g} / \mathrm{mL}$ of AEPa. Cells treated with M-CSF and AEPa presented filopodia (arrows), cytoplasmic vacuoles $\left({ }^{*}\right)$, mitochondria and abundant endoplasmic reticulae and presence of autophagic vacuoles (head arrows). Bars: 5 mm. N: Nucleus, M: Mitochondria, ER: Endoplasmic reticulum.

observed in the group treated with M-CSF and peritoneal macrophages (Figure 6e). Furthermore, CD11c labeling showed no significant difference in levels expression compared with untreated cells, AEPa treated cells or M-CSF group (Additional file 2), showing that AEPa and M-CSF does not stimulate the differentiation of BMCs into dendritic cells.

\section{Discussion}

A great number of herbal products have been used in folk medicine due to their immunomodulatory actions $[15,16,25,26]$. Extracts and physalins obtained from $P$. angulata exhibit diverse biological properties, including, analgesic, anti-inflammatory and immunomodulatory activities [18,19,27-29]. AEPa exhibits beneficial effects on carragenin-induced air pouch inflammation through its immunomodulatory action [19]; however, the direct action of AEPa on bone marrow remains unknown. Here, we demonstrate for the first time that AEPa has an immunomodulatory effect on BMCs, differentiating cells into macrophages. Chemical analyses from our group have found that aqueous extracts of the dried root of $P$. angulata contain physalins D, E, F and G (unpublished data). We hypothesize that the immunomodulatory effects of AEPa may derive from the presence of these physalins.

The differentiation of monocytes into macrophages or DCs in culture is most commonly achieved during 5 days, although a process of rapid differentiation within several hours can occur, depending on the stimulus used [30]. These interesting effects indicate that bone marrowderived monocytes differentiate into macrophages; however, not all cell types respond in this same manner during AEPa treatment.

A quantification experiment was performed to identify the presence of different cell types in these cultures. Lymphocyte numbers were found to be significantly reduced in BMCs treated with AEPa for 96 hours; as such, AEPa does not stimulate the adhesion and proliferation of this cell type. Bastos et al. [19] showed that AEPa had an inhibitory effect on lymphocyte proliferation, particularly on $\mathrm{T}$ cells. These results are in agreement with those observed by $\mathrm{Yu}$ et al. [31], who demonstrated that physalin $\mathrm{H}$ obtained from $P$. angulata presents an immunosuppressive activity, thus preventing the proliferation of T cells.

BMCs treated with AEPa showed a significant increase of mononuclear cells when compared to control. 

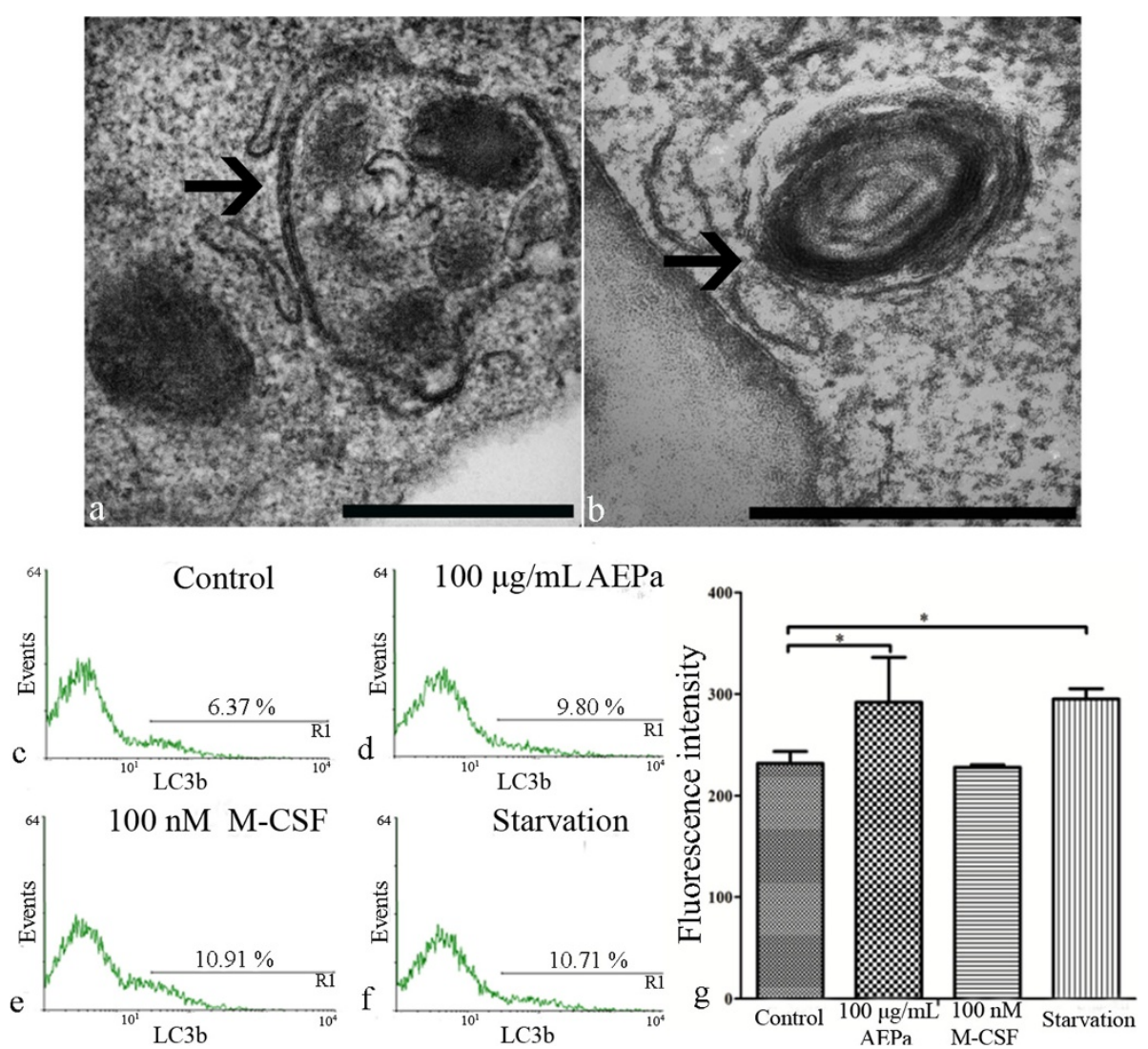

Figure 5 Detection of autophagic process in BMCs. Treated cells were incubated for 96 hours. a-b) Ultrastructural analysis of BMCs treated with AEPa. Cells treated with AEPa presented autophagic vacuoles in the cytoplasm (arrows). Bars: $0.5 \mu \mathrm{m}$. c) Untreated control. d) Cells treated with $100 \mu \mathrm{g} / \mathrm{mL}$ AEPa. e) Cells treated with $100 \mathrm{nM}$ M-CSF. f) Starvation. g) Fluorescence intensity of BMCs stained with LC3b. ANOVA followed by Tukey test, $\mathrm{p}<0.05$.

Morphological LM analysis showed that AEPa-treated cells had a higher spread ability and morphometric analysis revealed that treated cells showed an increase in cellular area. In addition, TEM demonstrated that BMCs, treated for 96 hours with $100 \mu \mathrm{g} / \mathrm{mL} \mathrm{AEPa}$, presented nuclei with abundant euchromatin, augmented ER, elongated mitochondria and the presence of numerous cellular projections. Several changes are observed during the process of differentiation of monocytes into macrophages such as altered expression of surface proteins, increased cell size, increased number of organelles and autophagic induction $[8,9]$.

Another characteristic feature seen in AEPA- and MCSF-treated BMCs was the presence of autophagic vacuoles in the cytoplasm, which was not observed in untreated cells. Analysis by flow cytometry revealed a significant increase in LC3b protein on treated cells, when compared to the control group, indicating an autophagy process. Autophagy is very important during the process of monocyte differentiation into macrophages, allowing the proliferation of these cells and preventing death by apoptosis [9]. The autophagic activation mechanism can be induced by various routes, one of which is by
ER stress, and the response of the organism to autophagy can be varied, allowing cell survival or leading to non-apoptotic death [32,33]. Our results show that AEPa-treated cells presented autophagic characteristics and this mechanism was not deleterious to the cells, since there was no reduction in cell viability. Thus, we may suggest that autophagy favors cell survival, allowing the differentiation of monocytes into macrophages.

Macrophages may elicit an altered pattern of surface markers, as compared to non-differentiated cells. The surface proteins, CD11b and F4/80, are examples of molecules that change after macrophage differentiation [34]. CD11b can be found on the surface of neutrophils, DCs, lymphocytes and macrophages, but is highly expressed on the monocyte surface [10]. However, the F4/80 molecule is expressed only on the macrophage surface [11]. Flow cytometry demonstrated a significant decrease in CD11b levels on AEPa-treated cells when compared to the control group. Results indicate that monocytes were the most common cell type in the untreated BMCs, because this group had a high staining for the CD11b protein. On the other hand, cells found 


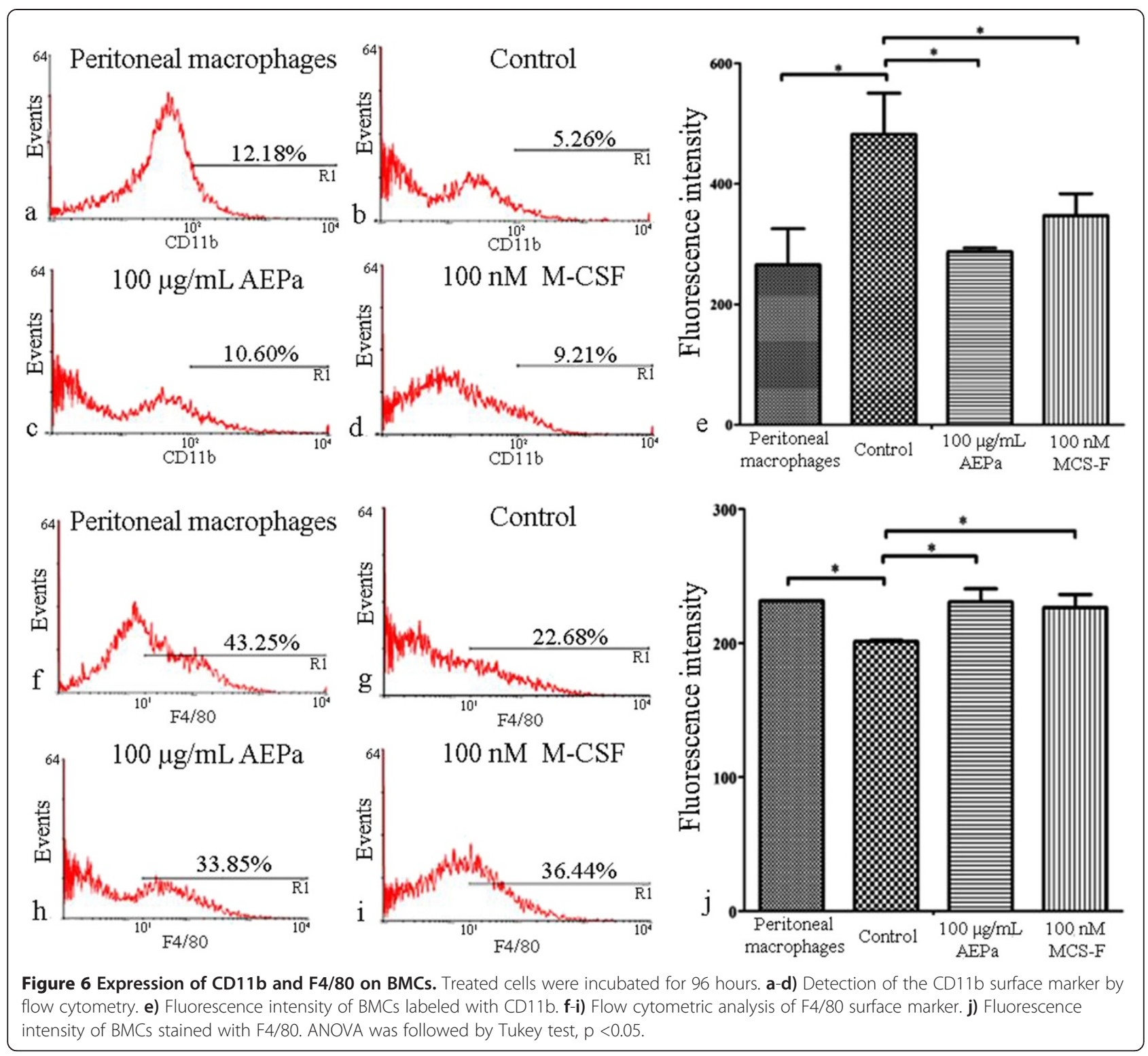

in the cultures treated with AEPa or M-CSF were mainly macrophages as demonstrated by the decrease in CD11b protein expression. To confirm that macrophages were the major cell type in the culture population, expression of the macrophage-specific protein, F4/ 80 , was determined. There was a significant increase in surface F4/80 on the AEPA-treated cells, where levels were similar to those observed in the positive control (peritoneal macrophages) and the M-CSF-treated group. These results suggest that AEPa potentiates the differentiation of monocytes into macrophages.

Another important immune cell type that is derived from the monocyte lineage is the DCs; these are antigen-presenting cells (APCs) that play a major role in bridging of the innate and adaptative immune responses. When monocytes migrate to tissues they can differentiate into macrophages or DCs [3]. In this study, we have used the surface marker, CD11c, to determine the presence of this cell type. No significant difference in the expression levels for CD11c on AEPatreated BMCs was observed. Thus, AEPa was not able to stimulate the differentiation and maturation of bone marrow mononuclear cells in DCs. It is important to emphasize that no cytotoxic effects were observed in the cells treated with AEPa. The search for new products, without cytotoxic effects on mammalian cells, is important for the development of agents that can induce the differentiation and/or maturation of BMCs into macrophages. Since these cells participate in the initiation of the innate immune response, such agents may be able to promote the protection against several intracellular pathogens $[12,26]$. 


\section{Conclusion}

AEPa seems to act on different aspects of cellular differentiation, with potential to act as an immunomodulatory agent, inducing the differentiation of BMCs into macrophages, which are important cells in the defense against pathogens.

\section{Additional files}

Additional file 1: Flow citometry of unstained BMCs controls elucidating gates for further analysis of treated cells.

Additional file 2: Detection of the CD11c surface marker by flow cytometry on BMCs. Treated cells were incubated for 96 hours. a) Untreated control. b) Cells treated with $100 \mu \mathrm{g} / \mathrm{mL}$ AEPa. c) Cells treated with $100 \mathrm{nM}$ M-CSF. d) Fluorescence intensity of BMCs labeled with CD11c. ANOVA followed by Tukey test. $p<0.05$.

\section{Abbreviations}

BMCs: Bone marrow cells; DMEM: Dulbecco's modified Eagle's medium; FBS: Fetal bovine serum; AEPa: Aqueous extract from root of Physalis angulata; M-CSF: Macrophage colony-stimulating factor; MTT: 3-(4,5-dimethylthiazol-2-yl)2,5-diphenyl tetrazolium bromide; PI: Propidium iodide; LM: Light microscopy; TEM: Transmission electron microscopy; BSA: Bovine serum albumine; DMSO: Dimethylsufoxide.

\section{Competing interests}

The authors declare that they have no competing interests.

\section{Authors' contributions}

BJMS performed all experiments and wrote the manuscript. LHSF and AAPH performed flow cytometry analysis. APDR performed the LM and TEM analyzes. BJMS, APDR, EOS and JLMN were involved in the discussion of results and manuscript editing. All authors read and approved the final manuscript.

\section{Acknowledgments}

This work was supported by the Conselho Nacional de Desenvolvimento Científico e Tecnológico (CNPq), Coordenação de Aperfeiçoamento de Pessoal de Nível Superior (CAPES), FAPESPA, PROPESP-UFPA and Instituto Nacional de Biologia Estrutural e Bioimagem-INBEB (CNPq - grant number 573767/2008-4). The authors are grateful to Gilmara Bastos to prepare and give the AEPa.

\section{Author details}

${ }^{1}$ Instituto de Ciências Biológicas, Laboratório de Parasitologia e Laboratório de Biologia Estrutural, Universidade Federal do Pará, Avenida Augusto Corrêa, 01, Bairro Guamá, 660975-110 Belém, Pará, Brazil. ${ }^{2}$ Instituto Nacional de Ciência e Tecnologia em Biologia Estrutural e Bioimagem, Rio de Janeiro, Brazil. ${ }^{3}$ Laboratório de Microscopia Eletrônica, Instituto Evandro Chagas, Secretaria de Vigilância em Saúde do Ministério da Saúde, Belém, Pará, Brazil. ${ }^{4}$ Instituto de Ciências Biológicas, Laboratório de Neuroquímica Molecular e Celular, Universidade Federal do Pará, Avenida Augusto Corrêa, 01, Bairro Guamá, 660975-110 Belém, Pará, Brazil.

Received: 22 May 2014 Accepted: 24 September 2014 Published: 3 October 2014

\section{References}

1. Travlos GS: Normal structure, function, and histology of the bone marrow. Toxicol Pathol 2006, 34(5):548-565.

2. Bryder D, Rossi DJ, Weissman IL: Hematopoietic stem cells: the paradigmatic tissue-specific stem cell. Am J Pathol 2006, 169(2):338-346.

3. Geissmann F, Manz MG, Jung S, Sieweke MH, Merad M, Ley K: Development of monocytes, macrophages, and dendritic cells. Science 2010, 327(5966):656-661.

4. Abdelhay ESFW, Braga FHP, Binato R, Bouzas LFS: Hematopoietic stem cells: expansion and perspectives for therapeutic use. Rev Bras Hematol Hemoter 2009, 31(1):2-8
5. Nakajima $\mathrm{H}$ : Role of transcription factors in differentiation and reprogramming of hematopoietic cells. Keio J Med 2011, 60(2):47-55.

6. Trembicki KA, Qureshi MA, Dietert RR: Avian peritoneal exudate cells: a comparison of stimulation protocols. Dev Comp Immunol 1984, 8(2):395-402.

7. Randolph GJ, Jakubzick C, Qu C: Antigen presentation by monocytes and monocyte-derived cells. Curr Opin Immunol 2008, 20(1):52-60.

8. Huber R, Pietsch D, Günther J, Welz B, Vogt N, Brand K: Regulation of monocyte differentiation by specific signaling modules and associated transcription factor networks. Cell Mol Life Sci 2014, 71(1):63-92.

9. Zhang Y, Morgan MJ, Chen K, Choksi S, Liu ZG: Induction of autophagy is essential for monocyte-macrophage differentiation. Blood 2012, 119(12):2895-2905.

10. Brom J, Köller M, Schlüter B, Müller-Lange P, Ulrich SH, König W: Expression of the adhesion molecule CD11b and polymerization of actin by polymorphonuclear granulocytes of patients endangered by sepsis. Burns 1995, 21(6):427-431.

11. Khazen W, M'bika JP, Tomkiewicz C, Benelli C, Chany C, Achour A, Forest C: Expression of macrophage-selective markers in human and rodent adipocytes. FEBS Lett 2005, 579(25):5631-5634.

12. Auffray C, Sieweke MH, Geissmann F: Blood monocytes: development, heterogeneity, and relationship with dendritic cells. Annu Rev Immunol 2009, 27:669-692.

13. Jin M, Jeon HJ, Jung HJ, Kim B, Shin SS, Choi JJ, Lee JK, Kang CY, Kim S: Enhancement of repopulation and hematopoiesis of bone marrow cells in irradiated mice by oral administration of PG101, a water-soluble extract from Lentinus lepideus. Exp Biol Med 2003, 228(6):759-766.

14. Nworu CS, Esimone CO, Tenbush M, Nabi G, Proksch P, Uberla K, Temchuva W: Adjuvant properties of AcF1, an immunostimulant fraction of Alchornea cordifolia extract. Immunol Invest 2010, 39(2):132-158.

15. Hamsa TP, Kuttan G: Ipomoea obscura ameliorates cyclophosphamideinduced toxicity by modulating the immune system and levels of proinflammatory cytokine and GSH. Can J Physiol Pharmacol 2010, 88(11):1042-1053.

16. Ghonime M, Eldomany R, Ablelaziz A, Soliman H: Evaluation of immunomodulatory effect of three herbal plants growing in Egypt. Immunopharmacol Immunotoxicol 2011, 33(1):141-145.

17. Magalhães $H I$, Veras ML, Torres MR, Alves AP, Pessoa OD, Silveira ER, Costa-Lotufo LV, De Moraes MO, Pessoa C: In-vitro and in-vivo antitumour activity of physalins B and D from Physalis angulata. J Pharm Pharmacol 2006, 58(2):235-241.

18. Bastos GN, Santos AR, Ferreira VM, Costa AM, Bispo Cl, Silveira AJ, Do Nascimento JL: Antinociceptive effect of the aqueous extract obtained from roots of Physalis angulata L. on mice. J Ethnopharmacol 2006, 103(2):241-245.

19. Bastos GN, Silveira AJ, Salgado CG, Picanço-Diniz DL, Nascimento JL: Physalis angulata extract exerts anti-inflammatory effects in rats by inhibiting different pathways. J Ethnopharmacol 2008, 118(2):246-251.

20. Shingu $K$, Yahara S, Okabe H, Nohara T: Three new withanolides, physagulins E, F and G from Physalis angulata L. Chem Pharm Bull (Tokyo) 1992, 40(9):2448-2451.

21. Ismail N, Alam M: A novel cytotoxic flavonoid glycoside from Physalis angulata. Fitoterapia 2001, 72(6):676-679.

22. Marim FM, Tatiana-Silveira N, Lima SDJR, Zamboni DS: A method for generation of bone marrow-derived macrophages from cryopreserved mouse bone marrow cells. PLoS One 2010, 5(12):152-163.

23. Fotakis G, Timbrell JA: In vitro cytotoxicity assays: comparison of $\mathrm{LDH}_{\text {, }}$ vermelho neutro, MTT and protein assay in hepatoma cell lines following exposure to cadmium chloride. Toxicol Lett 2006 , 160:171-177.

24. Sokol RJ, Hudson G, James NT, Frost IJ, Wales J: Human macrophage development: a morphometric study. J Anat 1987, 151:27-35.

25. Sato DY, Wal R, De Oliveira CC, Cattaneo RI, Malvezzi M, Gabardo J, Buchi DF: Histopathological and immunophenotyping studies on normal and sarcoma 180-bearing mice treated with a complex homeopathic medication. Homeopathy 2005, 94(1):26-32.

26. De Oliveira CC, Abud AP, e Oliveira SM, Guimarães FS, Andrade LF, Di Bernardi RP, Colleto EL, Kuczera D, Da Lozzo EJ, Gonçalves JP, Trindade ES, Buchi DF: Developments on drug discovery and on new therapeutics: highly diluted tinctures act as biological response modifiers. BMC Complement Altern Med 2011, 11(101):1-11.

27. Guimarães ET, Lima MS, Santos LA, Ribeiro IM, Tomassini TBC, dos Santos RR, dos Santos WLC, Soares MPB: Activity of physalins purified from 
P. angulata in vitro and in vivo models of cutaneous leishmaniasis. J Antimicrob Chemother 2009, 64(1):84-87.

28. Guimarães ET, Lima MS, Santos LA, Ribeiro IM, Tomassini TB, Dos Santos RR Dos Santos WL, Soares MB: Effects of seco-steroids purified from Physalis angulata L., Solanaceae, on the viability of Leishmania sp. Braz $J$ Pharmacogn 2010, 20(6):945-949.

29. Sá MS, Menezes MN, Krettli AU, Ribeiro IM, Tomassini TC, Ribeiro RS, Azevedo WFJR, Soares MB: Antimalarial activity of Physalins B, D, F, and G. J Nat Prod 2011, 74(10):2269-2272.

30. Vordenbäumen S, Braukmann A, Altendorfer I, Bleck E, Jose J, Schneider M: Human casein alpha s1 (CSN1S1) skews in vitro differentiation of monocytes towards macrophages. BMC Immunol 2013, 14(46):1-11.

31. Yu Y, Sun L, Ma L, Li J, Hu L, Liu J: Investigation of the immunosuppressive activity of Physalin $\mathrm{h}$ on T lymphocytes. Int Immunopharmacol 2010, 10(3):290-297.

32. Mei $Y$, Thompson MD, Cohen RA, Tong $X$ : Endoplasmic reticulum stress and related pathological processes. J Pharmacol Biomed Anal 2013, 1(2):1-8.

33. Mukhopadhyay S, Panda PK, Sinha N, Das DN, Bhutia SK: Autophagy and apoptosis: where do they meet? Apoptosis 2014, 19(4):555-566.

34. Smit E, Pretorius E, Anderson R, Oommen J, Potjo M: Differentiation of human monocytes in vitro following exposure to canova in the absence of cytokines. Ultrastruct Pathol 2008, 32(4):147-152.

doi:10.1186/1471-2121-15-37

Cite this article as: da Silva et al:: Physalis angulata induces in vitro differentiation of murine bone marrow cells into macrophages. BMC Cell Biology 2014 15:37.

\section{Submit your next manuscript to BioMed Central and take full advantage of:}

- Convenient online submission

- Thorough peer review

- No space constraints or color figure charges

- Immediate publication on acceptance

- Inclusion in PubMed, CAS, Scopus and Google Scholar

- Research which is freely available for redistribution 